\title{
Multiphase feeding program for broilers can replace traditional system
}

\author{
Luciano Hauschild* , Camila Ferreira Delfim Bueno, Aline Remus, Jaqueline de Paula Gobi, Renan Di Giovanni Isola, Nilva Kazue \\ Sakomura
}

São Paulo State University/FCAV - Animal Science Dept., Via de Acesso Prof. Paulo Donato Castellane, s/n - 14884-900

- Jaboticabal, São Paulo - Brazil.

*Corresponding author <lhauschild@fcav.unesp.br>

Edited by: Concepta Margaret McManus Pimentel
ABSTRACT: Broilers are traditionally managed with feeding programs that often consist of three or four phases. In this study we investigated whether a multiphase feeding program (14 phases) of broilers based on the optimal mix of two feeds could replace a traditional four phase system while maintaining broiler performance. To evaluate this prposed program we measured variables of performance, carcass yield, and nitrogen excretion. In addition, we determined if the multiphase feeding program (14 phases) would be equally effective regardless of bird gender. A total of 480 day-old Cobb chicks were used, with an average weight of $44.74 \pm 0.16 \mathrm{~g}$ (females) and $44.71 \pm 0.11 \mathrm{~g}$ (males). The birds were distributed in a completely randomized $2 \times 2$ factorial design. Each treatment consisted of six replicates with 20 animals per experimental unit. Results were analyzed separately in two periods (1-21 and 22-42 days) as determined by slaughter date, as well as for the entire growth period (1-42 days). The multiphase program led to improvements in final body weight and average daily weight gain, in addition to an increase in breast yield.

Keywords: Avinesp 1.0, precision nutrition, body composition, levels of lysine
Received June 13, 2014

Accepted September 18, 2014 environmental impact (Gutierrez et al., 2008; Pope and Emmert, 2001; Pope et al., 2002; Tolimir et al., 2010), but they did not consider the logistical shortcomings (only a two mixed feed in real time) associated with the need to formulate a diet for every feeding phase and a difference in nutrient requirements between male and female. In this study, we investigated whether a multiphase program of broilers based on the optimal mix of two feeds, could replace a traditional system while maintaining broiler performance and if it would be equally effective regardless of bird gender.

\section{Materials and Methods}

This study was conducted in Jaboticabal, in the

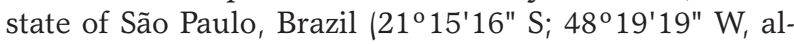
titude $607 \mathrm{~m})$.

\section{Animals and experimental design}

480 day-old Cobb chicks were used, with an average weight of $44.74 \pm 0.16 \mathrm{~g}$ (females) and $44.71 \pm 0.11$ $\mathrm{g}$ (males). Forty-eight chicks (six males and six females) nearest to the average body weight were slaughtered for initial body composition analyses (reference group). The remaining chicks were distributed in a completely randomized $2 \times 2$ factorial design (sex: male or female; feeding program: 4 or 14 phases).

Each treatment consisted of six replicates with 20 animals per experimental unit. During the experimental period, the birds were housed in pens with concrete floors and reused wood shavings, equipped with tubular feeders and nipple drinkers. Feed and water were provided ad libitum throughout the experimental period. Room temperature began at $33^{\circ} \mathrm{C}$ from day one to three and was reduced gradually to reach $24{ }^{\circ} \mathrm{C}$ at the end of the experiment, and the relative humidity was around 
$60 \%$.The lighting program was in line with the recommendations given in the broiler management guide.

\section{Nutritional requirements and diets}

Daily lysine requirements were estimated with the aid of AVINESP 1.0, and the level of other nutrients used followed the recommendations of Rostagno et al. (2011) for broiler male and females of superior performance. Two premixed A and B diets were formulated to meet the requirements for the first and last day of the experimental period (Table 1), respectively, with reference to the lysine requirement. To obtain the average requirement of this amino acid in the various phases of each program, both diets were mixed in different proportions according to the formulation method developed by Létourneau-Montminy et al. (2005).

The traditional program supply (four phases) afforded four diets, each replaced at the start of each predetermined period ( 1 to 7,8 to 21,22 to 35 , and 36 to 42

Table 1 - Proximate and nutrient composition of diets used to compose the treatment of nutritional programs for males and females.

\begin{tabular}{|c|c|c|c|c|}
\hline \multirow{3}{*}{ Ingredients (\%) } & \multicolumn{4}{|c|}{ Pre-mixtures } \\
\hline & \multicolumn{2}{|c|}{ Male } & \multicolumn{2}{|c|}{ Female } \\
\hline & A & $\mathrm{B}$ & A & $B$ \\
\hline Corn & 49.377 & 67.535 & 54.299 & 66.494 \\
\hline Soybean Meal (45 \%) & 42.558 & 26.637 & 37.246 & 22.500 \\
\hline Wheat Bran & 0.000 & 0.000 & 0.000 & 5.100 \\
\hline Soy Oil & 2.897 & 3.149 & 2.294 & 3.500 \\
\hline Dicalcium Phosphate & 2.593 & 1.105 & 2.626 & 0.963 \\
\hline Limestone & 0.797 & 0.738 & 1.597 & 0.702 \\
\hline Salt & 0.400 & 0.395 & 0.400 & 0.400 \\
\hline Mineral Premix ${ }^{1}$ & 0.100 & 0.100 & 0.100 & 0.100 \\
\hline Vitamin Premix ${ }^{2}$ & 0.408 & 0.052 & 0.512 & 0.011 \\
\hline HCl-Lysine (78 \%) & 0.408 & 0.052 & 0.512 & 0.011 \\
\hline DL-Methionine & 0.468 & 0.123 & 0.478 & 0.071 \\
\hline L-Treonine & 0.236 & 0.000 & 0.2811 & 0.000 \\
\hline Choline Chloride (60 \%) & 0.067 & 0.067 & 0.067 & 0.067 \\
\hline \multicolumn{5}{|l|}{ Calculated Composition } \\
\hline Crude Protein, \% & 24.00 & 17.60 & 22.15 & 16.41 \\
\hline ME, Mcal kg-1 & 2,960 & 3,200 & 2,960 & 3,263 \\
\hline Calcium, \% & 1.100 & 0.663 & 1.400 & 0.632 \\
\hline Available Phosphorus, \% & 0.600 & 0.309 & 0.600 & 0.289 \\
\hline Sodium, \% & 0.203 & 0.195 & 0.201 & 0.204 \\
\hline Lysine, \% Digestible & 1.503 & 0.849 & 1.455 & 0.738 \\
\hline Methionine, \% Digestible & 0.757 & 0.358 & 0.746 & 0.299 \\
\hline Met+Cys, \% Digestible & 1.082 & 0.620 & 1.048 & 0.548 \\
\hline Threonine, \% Digestible & 0.977 & 0.55 & 0.946 & 0.515 \\
\hline Tryptophan, \% Digestible & 0.281 & 0.198 & 0.252 & 0.182 \\
\hline \multicolumn{5}{|c|}{ 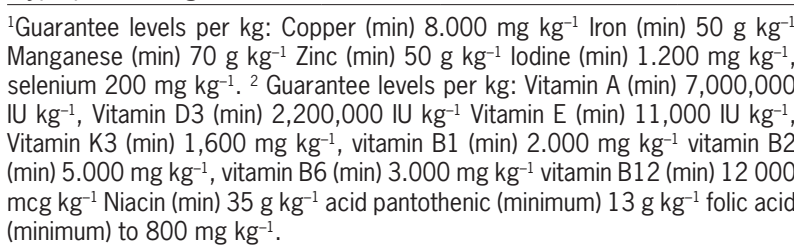 } \\
\hline
\end{tabular}

days old) and the same was done in the multiphase feeding program (14 phases), in which the diet was changed every three days, giving a total of 14 diets during the experimental period. The two premixed (A and B) for both groups of animals were weighed in a balance and after, mixed with a horizontal mixer.

\section{Experimental measurements}

The performance was evaluated at 1-21, 22-42, and 1-42 days of age through body weight, average daily feed intake, protein intake, daily weight gain, feed conversion, and protein and fat deposition. Two chicks from each pen nearest to the pen average body weight $1 \pm 10$ $\%$ ) were selected every 21 days from 0 to 42 days of age and slaughtered by asphyxiation with $\mathrm{CO}_{2}$. They were placed in individual plastic bags and kept deep frozen at $-20{ }^{\circ} \mathrm{C}$ prior to body composition analysis. On day 42 , two more chicks from each pen nearest to the pen average body weight $( \pm 10 \%)$ were selected and slaughtered by asphyxiation with $\mathrm{CO}_{2}$ to determine yield rating $(\%)$ of carcass, breast, wing, thighs, and drumsticks. The yield of the eviscerated carcass without head, neck, and feet was calculated according to body weight after fasting, while the yields from the cuts were calculated relative to the absolute weight of the carcass.

Prior to analysis, the frozen birds were then cut with a bandsaw and milled in an industrial meat grinder, homogenized, and aliquots removed for storage in Petri dishes and frozen again $\left(-20^{\circ} \mathrm{C}\right)$. The samples were then lyophilized, weighed again and later tested for total amount of dry matter, protein, and fat. Fat content of the carcass was obtained by extraction with petroleum ether in an Ancon unit and total nitrogen content in the degreased samples was quantified by the Kjeldahl method (AOAC, 2005).

Results from chemical analyses were used to estimate the protein and fat deposition in each period. The total deposition of protein or fat in the body weight was calculated for each pen on the basis of difference between the amounts at the beginning of the period and on the day of slaughter. The amounts at the beginning of the period were estimated from the initial BW-weight and BW composition of the reference group. The reference group for the first period (one day) consisted of 14 male and 14 female broilers slaughtered on the first day.

The reference groups for the second and last periods (21 and 42 days) consisted of two birds per pen from the first and last periods, respectively. Deposition rates for each period were calculated on the basis of total deposition divided by the length of the period ( 21 days). Nitrogen excretion was obtained from the difference between protein consumed $\left(\mathrm{CP}_{\text {cons }}\right)$ and body protein $\left(\mathrm{BP}_{\text {body }}\right)$ according to the equation: $\left(C P_{\text {cons }}-B P b o d y /\right.$ period).

\section{Statistical analysis}

Data were analyzed according to a $2 \times 2$ factorial arrangement using the GLM procedure from SAS (Sta- 
tistical Analysis System, version 9.3). The main characteristics included gender, feed program, and their interaction. For all response criteria, the pen served as the experimental unit. Variability in the data was expressed as the pooled SE, and a $p<0.10$ was considered to be statistically significant.

\section{Results}

Results were analyzed separately in two periods (1-21 and 22-42 days) as determined by slaughter date, as well as for the entire growth period (1-42 days). In the first period (Table 2), feeding programs influenced only body fat $(p<0.07)$, with a deposition $11 \%$ higher in the multiphase program (14 phases). All other variables were not influenced by the programs $(p>0.10)$, only by bird gender $(p<0.01)$. The effect of the program, however, on these variables did not depend on bird gender $(p>0.10)$.

In the second period (Table 3) final body weight was $3 \%$ higher $(p<0.03)$ in the multiphase program. The ADFI of multiphase program broilers was different (4\% higher) from that of broilers in the program with four phases $(p<0.05)$. The programs had no effect on
ADG $(p>0.10)$. Feed conversion was $1 \%$ worse in the multiphase program $(p<0.07)$. Similarly, protein intake was $4 \%$ higher for the multiphase program $(p$ $<0.095)$. The programs had no effect on protein deposition, fat deposition, body protein, or body fat in this phase $(p>0.10)$. Gender affected $(p<0.01)$ all variables except fat deposition and body fat $(p>0.10)$, and there was no interaction between gender and the feeding programs.

When the total period was analyzed (Table 4), final body weight $(p<0.05)$, ADFI $(p<0.10)$, and ADG $(p$ $<0.05)$ were $2 \%$ higher in the multiphase program. The programs had no effect on the remaining variables in this phase $(p>0.10)$. Table 5 also shows the analysis of cut yields. Total carcass yield was not influenced by the feeding program. Breast yield was $3 \%$ higher in the multiphase program $(p<0.05)$.

\section{Discussion}

The multiphase program led to improvements in final body weight, in addition to an increase in breast yield. Specifically, the use of the mixing method proposed by Létourneau-Montminy et al. (2005) can en-

Table 2 - Mean performance of male and female broilers fed with a multiphase program (14 phases) or traditional four phase program for the period 1-21 days.

\begin{tabular}{|c|c|c|c|c|c|c|c|c|}
\hline \multirow{3}{*}{$1-21$ days of age } & \multicolumn{4}{|c|}{ Feeding Program } & \multicolumn{3}{|c|}{ P-value } & \multirow{3}{*}{ SEM } \\
\hline & \multicolumn{2}{|c|}{ Four phases } & \multicolumn{2}{|c|}{ Multiphase } & \multirow{2}{*}{ Sex } & \multirow{2}{*}{$\operatorname{Pr}^{\mathrm{a}}$} & \multirow{2}{*}{ Int. ${ }^{b}$} & \\
\hline & Male & Female & Male & Female & & & & \\
\hline Final body weight, $g$ & 988.82 & 864.72 & 976.22 & 883.60 & 0.00 & 0.79 & 0.20 & 27.49 \\
\hline Daily feed intake, $\mathrm{g} \mathrm{d}^{-1}$ & 59.48 & 55.70 & 59.14 & 56.74 & 0.00 & 0.53 & 0.23 & 1.21 \\
\hline Body weight gain, $\mathrm{g} \mathrm{d}^{-1}$ & 44.95 & 39.02 & 44.34 & 39.93 & 0.00 & 0.79 & 0.19 & 1.30 \\
\hline Feed conversion & 1.32 & 1.45 & 1.33 & 1.43 & 0.00 & 0.36 & 0.14 & 0.02 \\
\hline Feed protein, $\mathrm{g} \mathrm{d}^{-1}$ & 12.18 & 10.69 & 12.14 & 10.65 & 0.00 & 0.77 & 0.97 & 0.32 \\
\hline Protein deposition, $\mathrm{g} \mathrm{d}^{-1}$ & 5.92 & 5.32 & 6.92 & 5.55 & 0.00 & 0.10 & 0.79 & 0.29 \\
\hline Fat deposition, $\mathrm{g} \mathrm{d}^{-1}$ & 2.87 & 3.76 & 2.88 & 3.91 & 0.00 & 0.77 & 0.78 & 0.53 \\
\hline Body protein, g (total) & 130.25 & 117.30 & 136.69 & 122.05 & 0.00 & 0.10 & 0.79 & 6.20 \\
\hline Body fat, g (total) & 62.79 & 80.59 & 66.48 & 92.11 & 0.00 & 0.06 & 0.30 & 6.78 \\
\hline
\end{tabular}

aPr. = program; lnt. = interaction; SEM = Standard error of mean; $\mathrm{F}$ test with $90 \%$ confidence interval (analysis of variance-covariance).

Table 3 - Mean performance of male and female broilers fed with a multiphase program (14 phases) or traditional four phase program for the period 22-42 days.

\begin{tabular}{|c|c|c|c|c|c|c|c|c|}
\hline \multirow{3}{*}{ 22-42 days of age } & \multicolumn{4}{|c|}{ Feeding Program } & \multicolumn{3}{|c|}{ P-value } & \multirow{3}{*}{ SEM } \\
\hline & \multicolumn{2}{|c|}{ Four phases } & \multicolumn{2}{|c|}{ Multiphase } & \multirow{2}{*}{ Sex } & \multirow{2}{*}{$\operatorname{Pr}^{\mathrm{a}}$} & \multirow{2}{*}{ Int. ${ }^{b}$} & \\
\hline & Male & Female & Male & Female & & & & \\
\hline Final body weight, $g$ & 3004.44 & 2440.04 & 3107.13 & 2513.07 & 0.00 & 0.03 & 0.69 & 85.36 \\
\hline Daily feed intake, $\mathrm{g} \mathrm{d}^{-1}$ & 170.84 & 147.67 & 177.95 & 152.43 & 0.00 & 0.09 & 0.73 & 7.90 \\
\hline Body weight gain, $\mathrm{g} \mathrm{d}^{-1}$ & 99.14 & 75.86 & 100.83 & 77.88 & 0.00 & 0.27 & 0.99 & 3.54 \\
\hline Feed conversion & 1.75 & 1.91 & 1.76 & 1.94 & 0.00 & 0.05 & 0.28 & 0.02 \\
\hline Feed protein, $\mathrm{g} \mathrm{d}^{-1}$ & 30.37 & 24.71 & 31.58 & 25.48 & 0.00 & 0.095 & 0.70 & 1.35 \\
\hline Protein deposition, $\mathrm{g} \mathrm{d}^{-1}$ & 16.47 & 10.54 & 15.10 & 10.95 & 0.00 & 0.46 & 0.18 & 1.26 \\
\hline Fat deposition, $\mathrm{g} \mathrm{d}^{-1}$ & 11.28 & 12.17 & 13.06 & 12.25 & 0.97 & 0.44 & 0.48 & 2.33 \\
\hline Body protein, g (total) & 459.46 & 336.89 & 455.95 & 352.00 & 0.00 & 0.61 & 0.42 & 27.12 \\
\hline Body fat, g (total) & 314.29 & 325.71 & 337.30 & 341.23 & 0.65 & 0.26 & 0.82 & 40.97 \\
\hline
\end{tabular}

${ }^{a P r} .=$ program; ${ }^{\text {Int }}$. $=$ interaction; SEM $=$ Standard error of mean; $\mathrm{F}$ test with $90 \%$ confidence interval. 
Table 4 - Mean performance of male and female broilers obtained by analysis of variance-covariance, fed multiphase program (14 phases) or four phases program, for the total period of growth.

\begin{tabular}{|c|c|c|c|c|c|c|c|c|}
\hline \multirow{3}{*}{$1-42$ days of age } & \multicolumn{4}{|c|}{ Feeding Program } & \multicolumn{3}{|c|}{ P-value } & \multirow{3}{*}{ SEM } \\
\hline & \multicolumn{2}{|c|}{ Four phases } & \multicolumn{2}{|c|}{ Multiphase } & \multirow{2}{*}{ Sex } & \multirow{2}{*}{$\operatorname{Pr}^{a}$} & \multirow{2}{*}{ Int. ${ }^{b}$} & \\
\hline & Male & Female & Male & Female & & & & \\
\hline Final body weight, $g$ & 3031.25 & 2440.04 & 3107.92 & 2480.34 & 0.00 & 0.043 & 0.50 & 55.36 \\
\hline Daily feed intake, $\mathrm{g} \mathrm{d}^{-1}$ & 115.18 & 100.04 & 118.85 & 101.70 & 0.00 & 0.08 & 0.49 & 3.13 \\
\hline Body weight gain, $\mathrm{g} \mathrm{d}^{-1}$ & 71.12 & 57.04 & 72.92 & 57.98 & 0.00 & 0.04 & 0.50 & 1.31 \\
\hline Feed conversion & 1.63 & 1.76 & 1.63 & 1.77 & 0.00 & 0.41 & 0.32 & 0.02 \\
\hline Feed protein, $\mathrm{g} \mathrm{d}^{-1}$ & 21.58 & 17.64 & 21.57 & 16.63 & 0.00 & 0.23 & 0.24 & 1.01 \\
\hline Protein deposition, $\mathrm{g} \mathrm{d}^{-1}$ & 10.80 & 7.93 & 10.71 & 8.25 & 0.00 & 0.72 & 0.54 & 0.59 \\
\hline Fat deposition, $\mathrm{g} \mathrm{d}^{-1}$ & 7.25 & 7.97 & 8.17 & 8.08 & 0.54 & 0.33 & 0.45 & 1.02 \\
\hline Body protein, g (total) & 447.09 & 336.84 & 455.91 & 351.96 & 0.00 & 0.27 & 0.77 & 26.67 \\
\hline Body fat, g (total) & 314.16 & 325.71 & 337.26 & 341.25 & 0.65 & 0.26 & 0.82 & 40.85 \\
\hline N excretion & 0.76 & 0.56 & 0.57 & 0.48 & 0.31 & 0.31 & 0.68 & 0.27 \\
\hline
\end{tabular}

${ }^{a P r} .=$ program; int. $=$ interaction; SEM $=$ Standard error of mean; $\mathrm{F}$ test with $90 \%$ confidence interval.

Table 5 - Average yield of carcass and commercial cuts of male and female broilers obtained by analysis of covariance, fed with a multiphase program (14 phases) or a traditional 4-phase program, at 42 days of age.

\begin{tabular}{|c|c|c|c|c|c|c|c|c|}
\hline \multirow{3}{*}{ Yield } & \multicolumn{4}{|c|}{ Feeding Program } & \multicolumn{3}{|c|}{ P-value } & \multirow{3}{*}{ SEM } \\
\hline & \multicolumn{2}{|c|}{ Four phases } & \multicolumn{2}{|c|}{ Multiphase } & \multirow{2}{*}{ Sex } & \multirow{2}{*}{$\operatorname{Pr}^{a}$} & \multirow{2}{*}{ Int. ${ }^{b}$} & \\
\hline & Male & Female & Male & Female & & & & \\
\hline Carcass (\%) & 75.41 & 74.47 & 75.75 & 74.87 & 0.05 & 0.42 & 0.95 & 1.46 \\
\hline Breast (\%) & 40.06 & 39.37 & 40.75 & 41.16 & 0.75 & 0.01 & 0.21 & 1.35 \\
\hline Thigh+drumstick (\%) & 27.68 & 27.66 & 27.23 & 27.26 & 0.99 & 0.10 & 0.92 & 0.77 \\
\hline Wing (\%) & 10.13 & 9.98 & 9.78 & 9.95 & 0.90 & 0.14 & 0.20 & 0.38 \\
\hline
\end{tabular}

aPr. = program; int. $=$ interaction; SEM $=$ Standard error of mean; $\mathrm{F}$ test with $90 \%$ confidence interval.

hance performance of broilers, even when compared with traditional four phase programs based on an average level of nutrient requirements for each phase. The applicability of logistic shortcomings was not our objective because this has already been examined by another study (Gutierrez et al., 2008). The important aspect for us was to evaluate broiler responses when fed with a multiphase program using a specific mixing method that follows nutrient requirements.

With the exception of body fat content, which was lower in the four phase program, there were no differences in performance and carcass yield between the feeding programs in the initial (1-21 days) growth phase. Pesti and Fletcher (1984) observed that feed conversion efficiency improves during the week following a period with inadequate protein intake, leading to an increase in the proportion of abdominal fat even though there is a decrease in total body fat content. This corroborates the observation that in the traditional program based on average nutrient requirements within a phase, birds experience a likely deficit in protein intake in the first half of each phase. Therefore, the lower body fat content in the traditional program could be a by-product of this mechanism.

Final body weight and feed intake were greater in the multiphase program in the second period (21-42 days), although feed conversion was more efficient in the traditional program. This is consistent with the previously mentioned notion that early protein restriction and lower fat content may subsequently improve feed efficiency (Gous et al., 2012; Moran, 1979; Pesti and Fletcher, 1984). However, no difference in carcass yield between programs was observed, which might be explained by a compensatory gain in the four phase program (Eits et al., 2003).

When the entire 42-day period is considered, there is an overall increase in final body weight and average daily gain in the multiphase program, which could be justified by the higher feed intake. Another aspect is that the differences in nutrient levels in the feed between programs may have also affected the results. While the multiphase program follows the bird's requirements, traditional programs based on average requirements necessarily provide lower or greater amounts of nutrients than those needed.

An increase in breast yield was also observed. This finding is in line with the proposition that for optimized breast yield, a constant protein intake, and thus protein input adjustment, is necessary during the entire growth period (Eits et al., 2003). Therefore, the compensatory growth observed in the traditional program was, in all likelyhood insufficient to generate an increase in breast yield, particularly in light of the adverse effects of the lower crude protein intake early in this phase.

In this study, we simulated a real situation in the traditional program where supplies are expensive and 
used the factorial method to define nutritional level in diets by considering the mean requirement of the population and the feed phase. When this method is employed in traditional feed programs (few phases), generally the average requirement for a period of time is used to minimize production costs (Hauschild et al., 2010). This implies a constant adjustment between nutritional input and requirements. Results indicate that such adjustment was accomplished in both programs, as nitrogen excretion was not affected by the program when the entire period was considered. We cannot rule out, however, the possibility that the differences observed in performance and carcass yield between feeding programs would have been even greater had we adjusted the traditional program (four phases) by the nutritional requirements based on the first and not the average day of each phase. Therefore, this study illustrates the need to better take into account the dynamic nature of nutrient requirements before making strategic nutritional decisions.

Overall, the mixing method proposed by Létourneau-Montminy et al. (2005) and previously used only in pigs (Pomar et al., 2007) can also be applied to the poultry industry to generate improvements in broiler performance, making possible the use of multiphase programs to adjust nutrient input in all phases of broiler growth. Therefore, this feeding program allows one to reach a precision feeding design that can contribute to the reduction and optimization of broiler farms, and ensure their economic viability.

\section{Conclusion}

The multiphase feeding program based on the mixing method allows for improving broilers' performance, in addition to increasing breast yield, as compared to a traditional program (four feeding phases).

\section{Acknowledgements}

To São Paulo State Research Foundation (FAPESP 2012/03781-0) for the grant that supported this study.

\section{References}

Association of Official Analytical Chemists - International [AOAC]. 2005. Official Methods of Analysis. 18ed. AOAC, Gaithersburg, MD, USA.

Buteri, C.B.; Tavernari, F.C.; Lelis, G.R.; Rostagno, H.S.; Albino, L.F.T. 2009. Effects of different nutritional plans on broiler performance. Brazilian Journal of Poultry Science 11: 225-234.

Eits, R.M.; Kwakkel, R.P.; Verstegen, M.W.A.; Emmans, G.C. 2003. Responses of broiler chickens to dietary protein: effects of early life protein nutrition on later responses. British Poultry Science 44: 398-409. Gous, R.M.; Emmans, G.C.; Fisher, C. 2012. The performance of broilers on a feed depends on the feed protein content given previously. South African Journal of Animal Science 42: 63-73.
Gutierrez, O.; Surbakti, N.; Haq, A.; Carey, J.B.; Bailey, C.A. 2008. Effect of continuous multiphase feeding schedules on nitrogen excretion and broiler performance. The Journal of Applied Poultry Research 17: 463-470.

Hauschild, L.; Pomar, C.; Lovatto, P. 2010. Systematic comparison of the empirical and factorial methods used to estimate the nutrient requirements of growing pigs. Animal 4: 714-723.

Létourneau-Montminy, M.P.; Boucher, C.; Pomar, C.; Dubeau, F.; Dussault, J. 2005. The impact of using different formulation methods and feeding programs on feeding cost and phosphorous and nitrogen excretion in growing-finishing pigs. Journées de la Recherche Porcine 37: 25-32 (in French, with abstract in English).

Moran, E.T. 1979. Carcass quality changes with broiler chickens after dietary protein restriction during growing phase and finishing period compensatory growth. Poultry Science 58: 1257-1270.

Nahm, K.H. 2007. Feed formulations to reduce $\mathrm{N}$ excretion and ammonia emission from poultry manure. Bioresource Technology 98: 2282-2300.

Pesti, G.M.; Fletcher, D.L. 1984. The response of male broiler chickens to diets with various protein contents during the grower and the finisher phases. British Poultry Science 25: 415-423.

Pesti, G.M.; Miller, B.R. 1997. Modelling for precision nutrition. The Journal of Applied Poultry Resource 6: 483-494.

Pomar, C.; Pomar, J.; Babot, D.; Dubeau, F. 2007. The impact of daily multiphase feeding on animal performance, body composition, and nitrogen and phosphorous excretion in growing-finishing pigs = Effet d'une alimentation multiphase quotidienne sur les performances zootechniques, la composition corporelle et les rejets d'azote et de phosphore du porc charcutier. Journées de la Recherche Porcine 39: 23-30 (in French).

Pope, T.; Emmert, J. L. 2001. Phase-feeding support maximum growth performance of broiler chicks from forty-three to seventy-one days of age. Poultry Science 80: 345-352.

Pope, T.; Loupe, L.N.; Townsend, J.A.; Emmert, J.L. 2002. Growth performance of broilers using a phase-feeding approach with diets switched every other day from forty-two to sixty-three days of age. Poultry Science 81: 466-471.

Rostagno, H.S.; Albino, L.F.T.; Donzele, J.L.; Gomes, P.C.; Oliveira, R.F.; Lopes, D.C.; Ferreira, A.S.; Barreto, S.L.T.; Euclides, R.F. 2011. Brazilian Tables for Poultry and Swine: Composition of Feedstuffs and Nutritional Requirements = Tabelas Brasileiras para Aves e Suínos: Composição de Alimentos e Exigências Nutricionais. 3ed. Editora UFV, Viçosa, MG, Brazil (in Portuguese).

Tolimir, N.; Perić, L.; Milošević, N.; Bogdanović, V. 2010. The effect of multiphase nutrition on production performances of broilers. Biotechnology in Animal Husbandry 26: 83-91. 